ACTA AGROBOTANICA

Vol. 59 z. 22006

s. 143150

\title{
Comparative analysis of the concentration of fungal spores in the air of Lublin and Rzeszów (Eastern Poland)
}

\section{IDALIA KASPRZYK ${ }^{1}$, ALEKSANDRA KONOPIŃSKA ${ }^{2}$}

\author{
Institute of Biology and Nature Protection, University of Rzeszów, Rejtana 16 c, \\ 35 959, Rzeszów, Poland \\ Department of Botany, University of Agriculture, Akademicka 15, 20950 Lublin, Poland \\ email: alexkonop@tlen.pl
}

(Received: 08.09.2006)

\section{$\mathrm{Su} \mathrm{m} \mathrm{m} \mathrm{a} \mathrm{r} \mathrm{y}$}

Studies of the concentration of fungal spores were carried out in the cities of Lublin and Rzeszów simultaneously in 2002. At both sites the volumetric method of measurement was applied, using the Lanzoni VPPS 2000 trap. Only the allergenic taxa were analysed: Alternaria, Botrytis, Cladosporium, Drechslera type, Epicoccum, Torula, Stemphylium, Pithomyces, Polythrincium, and Ganoderma. The research showed considerable differences in the concentration and frequency of spores in the air at the sites compared. Higher mean concentrations of spores were usually observed in Lublin. Only for two taxa were the concentrations higher in Rzeszów. No significant differences were observed for the genus of Polythrincium and Torula. Also the lengths of periods of occurrence of the spores were determined using the $95 \%$ method. It was determined that the geobotanical conditions in Rzeszów have a positive effect on the lengthening of the presence of the spores in aeroplankton. The results of the observations were analysed statistically, which confirmed the occurrence of significant differences between the cities compared.

Key words: aerobiology, fungi, spores, concentration, Eastern Poland, Lublin, Rzeszów, compa rative analysis

\section{INTRODUCTION}

The air contains numerous biotic and abiotic elements. Among aeroplankton particles, fungal spores are the most numerous. Some of the spores are harmless for other forms of life, whereas others cause diseases in plants, animals and humans, as well as damaging wood, metal, building materials and stored food ( $\mathrm{B} \mathrm{u} \mathrm{s} \mathrm{h}$ et al. 1964). The most important, from a medical point of view, and the commonest, are the spores of the artificial group of Fungi Imperfecti (anamorphic or conidial fungi). More rarely 
identified, though equally numerous, are Basidiomycotina and Ascomycotina spores (A d a m s, 1964).

The concentration of spores is shaped by many factors, which may be biological (daily sporulation rhythm, the availability of substrates for the development of mycelia), climatic and meteorological (temperature, humidity, precipitation), physical (movement of atmosphere, turbulence, convection) or seasonal (B e f f a et al. 1995; D'A mat o et al. 1995).

In Poland the first attempts at determining the content of fungal spores in the air were made in Kraków and Rabka in 1960 (We i s s , 2000). Volumetric measurements were started in 1992. Now the monitoring of fungal spore content is done in the scientific institutions of Kraków (S tę p a lsk a et al. 1999; Mę dral a-Ku der, 2000), Rabka (G a w e ł et al. 1996), Poznań (S t a c h , 2001), Lublin (K o n o p i ń s k a , 2003) and Rzeszów (K a s p r z y k et al. 2004). Some research was also done on the content of spores indoors (Górny et al. 1999; M y s zkow ska et al. 2002).

The aim of work was the comparison of concentrations of spores in two places located in different geobotanical units. Ten chosen allergenic taxa were studied.

\section{MATERIALS AND METHODS}

Airborne fungal spore concentration measurement was carried out in 2003 in two main cities of eastern Poland, i.e. Lublin and Rzeszów. The cities are located 131 $\mathrm{km}$ apart, in different geobotanical and climatic regions.

Lublin is located on the edge of two different climatic areas: highland and lowland Poland. Mean annual temperature is $7.4^{\circ} \mathrm{C}$ and mean annual precipitation is $550 \mathrm{~mm}$. The vegetation growth period is 200-210 days. In the Lublin area lindenoak-hornbeam forests, with an admixture of spruce, dominate. Both the wheat/sugar beet and rye/potato types of farming occur in the area.

The local climate of Rzeszów has a transitional character between lowlandfoothill climate and mountain climate (mean annual temperature $8.1^{\circ} \mathrm{C}$, annual precipitation $620-680 \mathrm{~mm}$ ). The vegetation growth period is $215-220$ days in this area. Natural vegetation of the region is dominated by mixed deciduous-coniferous forests, and hornbeam-dominated forests. Beech woods and oak woods can also be encountered in the area. The main farm crops are wheat and sugar beet.

The analysis of airborne spore concentration was made using the volumetric method with the application of Lanzoni VPPS 2000 type devices enabling continuous measurements. In both cities sampling sites were located in city centres among blocks of flats, near streets with heavy traffic. Due to differences in the installation conditions in the two sites the devices were fixed on roofs of different heights (in Rzeszów at $12 \mathrm{~m}$ and in Lublin at $18 \mathrm{~m}$ ).

Melinex tape was used as the base for the microscopic slides, which were covered by an adhesive layer. After completing a 7-day measurement cycle, the tape was divided into $48-\mathrm{mm}$ fragments corresponding to 24 intervals. The slides were analysed using an optic microscope. From among numerous kinds of airborne fungal spores the concentration of the following taxa was studied: Alternaria, Botrytis, Cladosporium, Drechslera type, Epicoccum, Torula, Stemphylium, Pithomyces, Polyth- 
rincium, and Ganoderma. All these taxa can be characterised by clear morphological features. The results were expressed as the number of spores $\cdot \mathrm{m}^{-3}$ per $24 \mathrm{~h}$. The main season of the occurrence of the airborne spores was determined using the 95\% approach and the sum of the spores was expressed as SFI (seasonal fungal index).

The statistical comparisons of results were made using a procedure proposed by Trigo et al. (2000). The taxa that had the same season of occurrence of spores (95\% method) in both cities were taken into account. In the first stage the normality of the distribution was tested using one-sample Kolmogorov-Smirnov test. The Spearman test was used to test the relationship between pairs of results originating from two sites. If a statistically significant relationship was found, the Wilcoxon test for pairs was used to test the null hypothesis that there are no differences between sites in the mean concentration of spores in a given period. In the case of the lack of significant differences, the Mann-Whitney U test was applied. Additionally the $\chi^{2}$ test was used to check if the distribution of the numbers of spores of the analysed types were the same. In all the tests significance level was set at $\alpha \leq 0,05$.

\section{RESULTS AND DISCUSSION}

Quantitative analysis of the occurrence of the ten studied airborne fungi spore taxa in Rzeszów and Lublin revealed that Cladosporium was the dominant taxon (90.6\% and $91.6 \%$ respectively). Another comparative study of five Polish towns Zakopane, Kraków, Poznań, Warszawa and Ostrowiec Świętokrzyski (S tę p als k a et al.1999) also showed a clear domination of Cladosporium in all sites. Even in other climatic regions this taxon is the commonest in the air (Comtois and Mandrioli, 1996; Larse n, 1981). The season of occurrence of the spores in the air started on the $15^{\text {th }}$ of April in Rzeszów and 25 days later (10.05) in Lublin. There was only one day's difference in the end of the season, which fell in Rzeszów on 22.10 and in Lublin on 23.10 (Tab. 1). In the case of fungal spores the seasonal fungal index SFI differs considerably between years and sites. It was also the case in this study, as in Lublin its values were much higher (Fig. 1) and the maximum concentration was nearly twice as high as in Rzeszów (Tab. 1).

The second most common taxon in Lublin was Alternaria 3.3\% (Tab. 1, Fig. 1). These results are similar to other literature data ( $\mathrm{S}$ e $\mathrm{n}$ et al. 2001). However in a region with a warm or semi-dry climate the proportion of airborne Alternaria spores can be even higher. Giner and Garcia (1995) found that they constituted $27.7 \%$ of spores in the town of Murcia (Spain). An increased concentration of Alternaria spores and of Helminthosporium, belonging to the same family, is associated with the cultivation of cereals and some Solanaceae plants, on which they occur as saprotrophs or parasites (H e r r e r o et al. 1996). The situation in Rzeszów was different and atypical, as the proportion of Alternaria spores was much lower (1.9\%) (Tab. 1) and SFI values were considerably lower, as in the case of Cladosporium (Fig. 1). Large differences were also observed in the length of the season. In Lublin it ranged from the 3rd of June to the 24th of September and was 52 days shorter than in Rzeszów (respectively 14.0411.10) (Tab. 1). 
Table 1

Results of descreptive statistics.

\begin{tabular}{lcccccccc} 
& \multicolumn{2}{c}{ Frequency $(\%)$} & \multicolumn{2}{c}{ MFA } & \multicolumn{2}{c}{ Begining of season } & \multicolumn{2}{c}{ End of season } \\
\hline Taxa & $\mathrm{Lu}$ & $\mathrm{Rz}$ & $\mathrm{Lu}$ & $\mathrm{Rz}$ & $\mathrm{Lu}$ & $\mathrm{Rz}$ & $\mathrm{Lu}$ & $\mathrm{Rz}$ \\
\hline Alternaria & 3,3 & 1,9 & 1583 & 615 & 03.06 & 24.04 & 24.09 & 11.10 \\
Botrytis & 1,2 & 1,1 & 479 & 213 & 20.03 & 28.03 & 05.10 & 17.10 \\
Cladosporium & 91,6 & 90,6 & 24444 & 14028 & 10.05 & 15.04 & 23.10 & 22.10 \\
Drechslera-type & 0,1 & 0,4 & 59 & 90 & 10.02 & 02.04 & 13.09 & 22.10 \\
Epicoccum & 0,3 & 1,2 & 127 & 204 & 24.05 & 03.05 & 03.10 & 31.10 \\
Ganoderma & 2,8 & 4,2 & 728 & 654 & 01.06 & 26.05 & 02.10 & 03.10 \\
Pithomyces & 0,1 & 0,1 & 42 & 42 & 01.07 & 19.06 & 02.10 & 19.09 \\
Polythrincium & 0,1 & 0,1 & 76 & 33 & 19.06 & 19.06 & 20.09 & 14.11 \\
Stemphylium & 0,1 & 0,1 & 19 & 39 & 23.05 & 23.05 & 22.10 & 18.10 \\
Torula & 0,2 & 0,3 & 49 & 48 & 06.02 & 06.02 & 13.10 & 15.11 \\
\hline
\end{tabular}

MFA maximum fungi appearance; $\mathrm{Lu}$ Lublin, Rz Rzeszów.

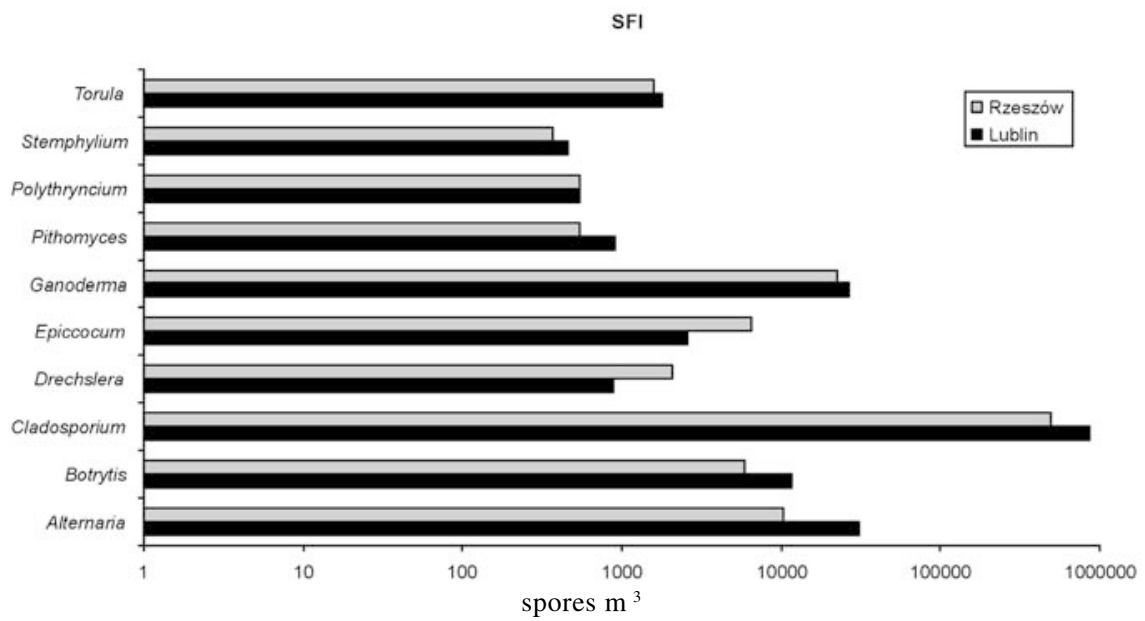

Fig. 1. Fungal spores frequency in the air of two sites in Eastern Poland. SFI Seasonal Fungal Index.

The season of occurrence of Ganoderma was similar in the two sites (Tab. 1, Fig. 1). It started and ended nearly at the same time (start: May 26th in Rzeszów and June 1st in Lublin, end: October 2th in Lublin and October 3rd in Rzeszów). Percentage proportion of the spores was different in the two sites. In Rzeszów it was the second most common spore type (4.2\%), whereas in Lublin it was the third $(2.8 \%)$. In the study done by Craig and Levetin (2000) in Tulsa (USA) in 1987-1996, Ganoder$m a$ spores were present in the air on $95 \%$ of days between June 1st and October 31 st. The maximum concentration of the spores in 1990 was only $12.4 \%$ of the concentration observed in Lublin, whereas in 1994 it exceeded the Lublin value by $31 \%$.

Botrytis spores had a similar period of occurrence in the two cities: 20.03-5.10 in Lublin and 28.03-17.10 in Rzeszów; however the maximum concentration of the spores was twice as high in Lublin $\left(479 \cdot \mathrm{m}^{-3}\right)$ than in Rzeszów $\left(213 \cdot \mathrm{m}^{-3}\right)$ and the SFI 
Table 2

The results of Spearman's test.

\begin{tabular}{|c|c|c|c|}
\hline Taxa & $\mathrm{n}$ & $\mathrm{r}$ & $\mathrm{R}^{2}$ \\
\hline Alternaria & 113 & $0.440 ;$; 水 & 19.36 \\
\hline Botrytis & 192 & $0.282 ; * *$ & 7.95 \\
\hline Cladosporium & 166 & 0.256 ; 水水 & 6.55 \\
\hline Drechslera-type & 165 & $0.308 ; *$ & 9.49 \\
\hline Epicoccum & 133 & $0.292 ; * *$ & 8.52 \\
\hline Ganoderma & 124 & $0.294 ;$ * ** & 8.64 \\
\hline Pithomyces & 81 & $0.350 ;$ * & 12.25 \\
\hline Polythrincium & 94 & $0.141 ; \mathrm{NS}$ & \\
\hline Stemphylium & 149 & $0.262 ;$ 非 & 6.86 \\
\hline Torula & 236 & $0.310 ;$; 水 & 9.61 \\
\hline
\end{tabular}

$\alpha \leq 0,01 ; * * \quad \alpha \leq 0,001$; NS not significant

Table 3

The results of Wilcoxona (z) i U Mann Whitney (Z) tests.

\begin{tabular}{lc}
\hline Taxa & $\mathrm{Z}$ \\
\hline Alternaria & $8.347 ; * *$ \\
Botrytis & $5.709 ; * * *$ \\
Cladosporium & $5.018 ; * *$ \\
Diechslera-type & $-6.168 ; * *$ \\
Epicoccum & $-5.895 ; * *$ \\
Ganoderma & $2.848 ; *$ \\
Pithomyces & $3.735 ; * *$ \\
Polythrincium & $0.478(\mathrm{Z}) ; \mathrm{NS}$ \\
Stemphylium & $3.083 ; *$ \\
Torula & $1.888 ; \mathrm{NS}$ \\
\hline
\end{tabular}

$\alpha \leq 0,01 ; * * \quad \alpha \leq 0,001$; NS not significant

value was much lower. (Fig. 1). A much higher maximum spore content in the air, reaching $1009 \cdot \mathrm{m}^{-3}$, was recorded by Diaz et al. (1997). This difference is probably caused by the climatic conditions of north-western Spain (Ourense), which are much more conducive to the development of the fungus. The percentage of spores of this taxon was similar in both studied sites (1.1\%-1.2\%, Tab. 1). For comparison, in Sophia 
(Yankova and Peneva, 1996), Botrytis had as much as an $11 \%$ contribution to the spore count. The taxa that were more numerous in Rzeszów than in Lublin were Epicoccum and Drechslera (Fig. 1). The spores of Epicoccum occurred in the air of Lublin between May 24th and October 3th, they constituted $0.3 \%$ of the annual sum of all the spores, and their highest concentration ( 127 spores $\cdot \mathrm{m}^{-3}$ ) was low compared to Rzeszów (204 spores. $\mathrm{m}^{-3}$ ). In the latter the occurrence season was longer by 49 days and lasted from May 3rd to October 31st (Tab. 1). As far as Drechslera is concerned, its concentration in aeroplankton is higher in Rzeszów $(0.4 \%)$ than in Lublin $(0.1 \%)$. In the former city the SFI was also higher, as well as the maximum concentration of spores (90 spores $\cdot \mathrm{m}^{-3}$ ) compared to $59 \cdot \mathrm{m}^{-3}$ in Lublin. Its season started much earlier in Lublin but ended much later in Rzeszów (Tab. 1).

Pithomyces, Polythrincium, Stemphylium and Torula had very low SFI values and constituted a low percentage of spore count in both sites (Tab. 1, Fig. 1). Similar results were obtained by Hen ri que z et al. (2001) in Santiago, Chile.

For most taxa the occurrence season of spores started earlier in Rzeszów and lasted longer there (Tab. 1). Only the occurrence period of Drechslera spores was longer in Lublin. This may be caused by a different land use type or different vegetation which constitute the habitat of the fungus. The season of occurrence of airborne spores is related to the phenology of vegetation. In the Rzeszów region mean annual temperature is higher than in Lublin and the vegetation growth period lasts longer. This might have brought about the prolonging of the occurrence of the spores. However local meteorological conditions could have had a strong impact as well. In order to study this relationship in detail, climatic elements should be taken into account.

Out of the analysed material only the occurrence of genus Ganoderma in Lublin was characterised by normal distribution (Kolmogorov-Smirnov test), therefore for further statistical analysis only non-parametric tests were used. The analysis confirmed the existence of considerable differences between the studied sites. The distribution of the analysed spore taxa in the studied sites was different $\left(\chi^{2}\right.$ test). The Spearman test (Tab. 2) showed highly significant correlation of the concentration of spores between the two sites for all the taxa except Polythrincium. In spite of the above-mentioned regularities, it is not possible to explain the daily dynamics in the sites. The percentage of explained variance is very low. Only in around a dozen cases was a growth in spore concentration in one site coupled with a similar growth in the other. The highest degree of compatibility was found in Alternaria and Pithomyces. Thus predicting concentrations using data from one site is impossible. Significant differences in the mean concentration of spores in the studied period (Tab. 3) were found. Higher mean concentrations of Cladosporium, Alternaria, Botrytis, Ganoderma, Pithomyces and Stemphylium were recorded in Lublin, and of Epicoccum and Drechslera in Rzeszów. Only in the concentrations of Torula and Polythrincium were there no significant differences. It must be emphasised that in spite of the fact that the Rzeszów region is warmer with more abundance of precipitation, in most instances allergenic spores were found in higher concentrations in Lublin. The Lublin area is a typically agricultural region with large-scale plantings of crops and most airborne fungal spores are plant pathogens. This may indicate the importance of the substrate suitable for the mycelia for the increase in the airborne spore concentrations. 


\section{Conclusions}

Analysis of the results shows clear-cut differences between the studied sites. They differ in the course of the occurrence season of airborne spores, and their quantitative spectrum. As a rule, higher concentrations of allergenic fungal spores were observed in Lublin. The results of this study indicate that it is not possible to use the concentrations of spores in one measurement site for prognostic purposes. Explaining the causes of the differences is extremely difficult due to the variety of factors influencing the phenomenon. Some of these are very difficult to determine or predict e.g. agricultural practices, changes in land management and anomalous weather. However, this research proves that it is necessary to extend the network of stations which monitor the concentration of spores in the air, and to set up permanent study sites which will work for many years.

\section{REFERENCES}

Ad a m s K. F., 1964. Year to year variation in the fungus spore content of the atmosphere. Acta Allergologica, 19: 1150.

Beffa T., Fischer J. L., Aragno M., 1995. Industrial sources and dispersion in the air of fungal spores. Mycologia Helvetica, 7 (2): 125130.

Bush R. K., Portnoy J. M., 2001. The role and abandment of fungal allergens in allergic diseases. J. Allergy Clin. Immunol. 107: 430440.

Comtois P., Mandrioli P., 1996. The aerobiological results from the 1994 cruise of the Urania (cnr) on the Adratic. I. Pollen and spore counts on the Mediterranean sea as compared to mainland Italia. Aerobiologia, 12: 167172.

Craig R. L., Levetin E., 2000. Multi year study of Ganoderma aerobiology. Aerobiologia, 16: 7581 .

D'A mato G., S piek s m a F. Th. M., 1995. Aerobiologic and clinical aspects of mould allergy in Europe. Allergy, 50: 870877.

Di a z M. R., Igles s a s I., J a to V. M., 1997. Airborne concentration of Botrytis, Uncinula and Plasmopara spores in vineyard in Leiro Ourense (N.W. Spain). Aerobiologia, 13: 3135.

Gaweł J., Halota A., Piesiewicz, Kurzawa R., Radliński J., Doniec Z., 1996. Allergenic airborne sporomorphs calendar for Rabka (Southern Poland), 19911995. Ann. Agric. Environ. Med. 3: 8798.

Gine r M. M., Garcia J. S. C., 1995. Daily variations of Alternaria spores in the city of Murcia (semi arid southern Spain). Relationship with weather variables. Int J Biometeorol, 38: 176179.

Govi G., 1992. Aerial diffusion of phytopathogenic fungi. Aerobiologia, 8: 8493.

Górny R. L., Dutkiewicz J., Krysińska Traczyk E., 1999. Size distribution of bacte rial and fungal bioaerosols in indoor air. Ann. Agric. Environ. Med., 6: 105113.

Henriquez V. I., Villegas G. R., Nolla J. M. R., 2001. Airborne fungi monitoring in Santiago, Chile. Aerobiologia, 17: 137142.

Herrero B., Fombella Blanco M. A., Fernández González D., Valencia Bar re r a R. M., 1996. Aerobiological study of fungal spores from Palencia (Spain). Aerobio logia, 12: 2735 . 
Kasprzyk I., Rzepowska B., Wasylow M., 2004. Fungal spores in the atmosphere of Rzeszow (South East Poland). Ann. Agric. Environ. Med., 11: 285289

Konopińska A., 2003. Sezonowe zmiany koncentracji zarodników Alternaria w Lublinie w latach 2001 2002. [Seasonal changes in the concentration of Alternaria spores in Lublin in 2001 2002.] Ann. Univ. Mariae Curie Skłodowska, sect. EEE, Hortic. Vol XIII: 377382 .

Larsen L. S., 1981. A three year survay of microfungi in the air of Copenhagen 197779. Allergy, 36: 1522.

Mędrala Kuder E., 2000. Mycological air pollution at sites of heavy traffic in Cracow. Acta Biologica Cracoviensia, series Botanica, 42 (1): 2124.

Myszkowska D., Stępalska D., Obtułowicz K., Porębski G., 2002. The relation ship between airborne pollen and fungal spore concentrations and seasonal pollen allergy symptoms in Cracow in 1997 1999. Aerobiologia, 18: 153161.

S en B., A s a n A., 2001. Airborne fungi in vegetable growing aeras of Edirne, Turkey. Aerobio logia, 17: 6975 .

Stach A., 2001. Pyłek roślin w aeroplanktonie Poznania w latach 19941997 ze szczególnym uwzględnieniem pyłku roślin taksonów alergogennych. Praca doktorska. [Pollen in aero plankton of Poznań in 19941997 with particular attention to the pollen of allergenic taxa. Doctoral thesis.] Archiwum Instytutu Botaniki UJ.

Stępalska D., Harmata K., Kasprzyk I., Myszkowska D., Stach A., 1999. Occu rence of airborne Cladosporium and Alternaria spores in Southern and Central Poland. Aerobiologia, 15: 3947.

Trig o M., Toro F. J., Re ci o M., Cabezud o B., 2000. A statistical approach to comparing the resaults from different aerobiological stations. Grana, 39: 252258.

Weis s A., 2000. Über das Pilzsporenvorkommen in der Luft in Kraków und Rabka. Allerg Asthma: 298303.

Yank ov a R., Pen e va R., 1996. Allergenic airborne spores in Sofia. Preliminary report. Mikol Lek, 1: 1317.

\section{Analiza porównawcza stężenia zarodników grzybów w powietrzu Lublina i Rzeszowa (wschodnia Polska)}

Badania koncentracji zarodników grzybów w powietrzu prowadzono równocześnie w Rzeszowie i Lublinie w roku 2002. Na obydwu stanowiskach zastosowano wolumetryczną metodę pomiaru przy użyciu aparatu pułapkowego Lanzoni VPPS 2000. Analizowano taksony alergenne: Alternaria, Botrytis, Cladosporium, Drechslera typ, Epicoccum, Torula, Stemphylium, Pithomyces, Polythrincium, Ganoderma. Przeprowadzone badania wykazały wyraźne różnice w koncentracji i frekwencji zarodników w powietrzu na porównywanych stanowiskach. Wyższe średnie wartości stężeń zarodników w większości przypadków zaobserwowano w Lublinie. Tylko dla dwóch taksonów wartości te były wyższe w Rzeszowie. Istotnych różnic nie stwierdzono dla rodzaju Polythrincium i Torula. Metodą 95\% wyznaczono długość okresu występowania zarodników w powietrzu. Stwierdzono, iż warunki geobotaniczne Rzeszowa wpływają korzystnie na wydłużenie okresu obecności zarodników w aeroplanktonie. Wyniki obserwacji poddano analizie statystycznej, która potwierdziła występowanie istotnych różnic pomiędzy badanymi stanowiskami. 